DEMOGRAPHIC RESEARCH

VOLUME 33, ARTICLE 31, PAGES 909-938 PUBLISHED 28 OCTOBER 2015

http://www.demographic-research.org/Volumes/Vol33/31/

DOI:10.4054/DemRes.2015.33.31

Research Article

Inter-generational co-residence and women's work and leisure time in Egypt

Nadia Diamond-Smith

David Bishai

Omaima El Gibaly

(C) 2015 Diamond-Smith, Bishai \& El Gibaly.

This open-access work is published under the terms of the Creative Commons Attribution NonCommercial License 2.0 Germany, which permits use, reproduction \& distribution in any medium for non-commercial purposes, provided the original author(s) and source are given credit.

See http:// creativecommons.org/licenses/by-nc/2.0/de/ 


\section{Table of Contents}

1 Introduction 910

1.1 Family structure, aging, and caregiving 911

$1.2 \quad$ Women's labor and leisure 912

$1.3 \quad$ Conceptual model and measures 913

$2 \quad$ Data and methods 916

2.1 Data 916

2.2 Variable construction 918

$\begin{array}{lll}2.3 & \text { Methods } & 920\end{array}$

$\begin{array}{lll}2.4 & \text { Robustness tests } & 921\end{array}$

$3 \quad$ Results 922

3.1 Characteristics of daughters-in-law and their mothers-in-law 922

3.2 Odds of having worked in the last three months (Table 4) 925

3.3 Minutes of time spent in work activities (Table 5) 926

3.4 Minutes of time spent in leisure (Table 6) 928

$4 \quad$ Discussion 929

4.1 Mothers-in-law, disability, household structure, and women’s work 929

4.2 Relationship between variables related to women's empowerment 930 and work and leisure

$5 \quad$ Conclusions 933

$6 \quad$ Acknowledgements 933

$\begin{array}{ll}\text { References } & 934\end{array}$ 


\title{
Inter-generational co-residence and women's work and leisure time in Egypt
}

\author{
Nadia Diamond-Smith ${ }^{1}$ \\ David Bishai $^{2}$ \\ Omaima El Gibaly ${ }^{3}$
}

\begin{abstract}
BACKGROUND

Labor force participation among women in Egypt remains low. Due to low fertility and increases in life expectancy, in the future women in Egypt may spend more time coresiding with aging in-laws. Past literature has suggested that in some settings coresidence allows women to enter the labor force, as mothers-in-law help care for their grandchildren, or inhibits labor force participation, when mothers-in-law reinforce traditional values or require care. There is little research on co-residence and labor supply or leisure time in Egypt, especially accounting for mother-in-law disability status.
\end{abstract}

\section{OBJECTIVE}

This paper examines the role of intergenerational co-residence in women's work, work time, and leisure time using data on time allocation in Egypt.

\section{METHODS}

Data were collected from 548 women with a living mother-in-law: 291 co-residing their mother-in-law and 257 not. Survey data included work status, a 24-hour time diary, and a health assessment of the mother-in-law. Multivariate regression models predicted work, work time, and leisure time use using standard models.

\section{RESULTS}

Co-residing with a disabled mother-in-law was associated with decreased odds of women working and fewer minutes spent working a day. Leisure time was not associated with the co-residence and disability status of a mother-in-law. Factors related

\footnotetext{
${ }^{1}$ University of California, San Francisco, CA, and Johns Hopkins Bloomberg School of Public Health, U.S.A. E-Mail: nadia.diamondsmith@gmail.com.

${ }^{2}$ Johns Hopkins Bloomberg School of Public Health, Baltimore, MD, U.S.A.

${ }^{3}$ Department of Public Health, Faculty of Medicine, Assiut University, Assiut, Egypt.
} 
to couples' relationships and the woman's views on gender norms were also associated with women working.

\section{CONCLUSIONS}

Co-residence appears to be associated with women's work, depending on the disability status of the co-residing mother-in-law. If increased life expectancy is associated with more time spent in a disabled state for mothers-in-law, this could put downward pressure on women's work in this setting.

\section{Introduction}

The patriarchal nature of Egyptian society leads to a high prevalence of intergenerational co-residence, where aging parents, especially mothers-in-law, live with their eldest son and daughter-in-law (Yount 2005; Yount et al. 2012). The higher fertility regimes of the past distributed the stewardship of parents and senior kin among more offspring. Fertility has fallen in Egypt in recent years, although it increased from 3.0 to 3.6 in the 2014 compared to the 2008 Demographic and Health Survey (Ministry of Health and Population, El-Zanaty and Associates, and The DHS Program ICF International 2014). Lower fertility combined with Egypt's rapidly aging population will result in more seniors and fewer younger adults in the future (United Nations 2011; United Nations World Statistics Pocketbook). Although there has not yet been a significant change in the co-residence structure of older adults, declines in fertility and increases in life expectancy may lead to younger generations having higher exposure to seniors in households in the near future (Yount and Sibai 2009).

Co-residing elderly parents may contribute to the household in terms of income, assets, or caregiving for children; or they may require care, especially as they age and experience disabilities. Most often, the burden of caregiving for co-residing kin falls on women in Egypt, as elsewhere (Yount 2005). There is a growing body of research on intergenerational flows of care and resources, and old age disability in Egypt and the Middle East. Most of this research looks at the relationship between biological children and their own parents (Yount et al. 2012). There is limited research on the impact of coresidence, care giving, and old-age disability on daughters-in-law.

The goal of this paper is to estimate how work and leisure time for childbearingage women vary with the disability status of co-residing mother-in-laws. We focus on two main competing uses of women's time which may be affected by caring for disabled parents-in-law: women's work and leisure time. Past literature on Egyptian families has suggested that co-residence with sons is much more common for older women than for older men, and although women might also provide care for their own 
parents, they are unlikely to co-reside with them (Yount 2005). Hence, this analysis focuses on the mother-in-law/daughter-in-law dyad. Below we discuss the literature motivating our focus on co-residence, care giving, leisure time, and work among women of reproductive age in Egypt.

\subsection{Family structure, aging, and caregiving}

Across the life course, the effect of parents on children's labor supply changes. Most parents are in their 40s and 50s when their children are entering the labor force and starting families. At this point in time, they themselves could be working, but may have the flexibility to assist with the care of grandchildren and thereby facilitate the labor supply of their daughters and daughters-in-law. The presence of parents with disabilities when women first become eligible to join the labor force remains rare, but senior-parent disabilities are likely to grow in frequency later in the life course. The parents of adults may first supply caregiving (for grandchildren), enabling young adult labor supply, and then, if disabilities increase, seniors may demand care during their children's $4^{\text {th }}$ and $5^{\text {th }}$ decades.

Past literature has suggested that one of the roles of a mother-in-law is to enforce traditional gender norms on her daughter-in-law (Vatuk 1998). Selective co-residence choices may partially account for this observation. Especially due to the role of families in match-making, more traditional women may marry more traditional men (with more traditional parents), who then make a choice to move in with the husband's family, and are already less predisposed to work outside the home. In the case of Egypt, marital matching norms may lead more traditional families to marry their children to each other, thereby ensuring that more traditional mothers-in-law have more traditional daughters-in-law.

Cultural expectations could impact a mother-in-law's willingness to help in the house or her expectations about the care she will receive. Research from Egypt exploring the role of women over the life course has found that women of reproductive age do most of the household labor, and mothers-in-law share in childcare (Lane and Meleis 1991). Lane and Meleis (1991) describe how when a young married Egyptian woman moves in with her mother-in-law, "daughters-in-law grow very lean, and mothers-in-law grow plump in inverse proportion” (p. 1201). Norms of patriarchy are enforced by this system, as mothers are incentivized to build strong ties with sons, with the knowledge that someday those sons will marry, the son's wives will move into the house, and that daughter-in-law will be required to take over the bulk of responsibilities in the household and in caring for the mother as she ages (Yount et al. 2012). 
Past research has suggested that there is a trade-off between the time one child provides to care for aging parents and the resources that their siblings provide to the aging parents (Knodel et al. 2000). Detailed work looking at intergenerational transfers between daughters, sons, and parents found that co-residing with a child significantly increased the odds of a parent receiving care in the form of transportation, chores, communication, and activities of daily living (getting out of bed, getting dressed, eating, walking, etc.) (Cunningham et al. 2013).

\subsection{Women's labor and leisure}

Women's labor force participation remains low in Egypt, with the World Bank reporting 27\% of adult women in the labor force in 2006 (World Bank 2010). Some estimates have put this number higher, closer to $60 \%$, when a broader definition of work is used (Langsten and Salem 2008). Recently in some countries in the Middle East and North Africa (MENA) region, such as Morocco and Tunisia, female labor force participation has begun to increase, yet Egypt lags behind its regional neighbors (Assaad 2004). Although the overall trend over time has been of increasing female labor force participation in Egypt, there is evidence of decreases in labor force participation among well-educated young women (Assaad 2009). Female labor force participation is often a family decision, and past research in the MENA region has suggested that women are more likely to work outside the home if the men in the household have a positive view of female labor force participation (Antecol 2003). Many questions remain about why women's labor supply is low in Egypt and what other factors must be considered to understand the drivers or barriers to women's labor force participation.

Standard models of women's labor supply have focused on tradeoffs between leisure, formal sector labor, and household labor, which includes "care responsibilities" (Becker 1981). Care responsibilities in the home include raising children and, later in the life course, assisting seniors. In cultures with gendered childcare roles, childcare responsibilities inhibit female labor force participation. Research in Morocco found that while marriage itself does not reduce female labor force participation, bearing children (especially more than two) significantly reduces women's labor force participation, particularly in the non-governmental and private markets (Assaad and Zouari 2003). Research in Egypt showed that marriage and childbearing decreased a woman's time spent in the formal sector and increased her time spent on domestic work (Hendy 2011). This research found that the first child increased a woman's time spent on domestic work by 20 hours a week and decreased the time spent in formal work by one hour a week (Hendy 2011). 
Like caring for children, caring for an aging parent must take time away from other tasks. There is an extensive and mixed literature on tradeoffs between caring for seniors and female labor force participation, some finding evidence of a tradeoff, and others finding that caring for an aging parent does not reduce the amount of time women spend in the labor force, since co-residing parents can provide care for young children, freeing up time for formal work (Johnson and Lo Sasso 2006; Latif 2006; Maurer-Fazio et al. 2011; Sasaki 2002; Wakabayashi and Donato 2005; Wolf and Soldo 1994). Qualitative research in Egypt has suggested that with rising levels of female employment, there is increasing tension between women's labor force participation and their ability to care for aging in-laws (Sinunu, Yount, and El Afify 2008). Especially among wealthier, urban, and more-educated households, there is evidence that families are beginning to seek formal care or non-family member care options for aging parents (removing the burden from daughters-in-law). This trend could spread to social strata below the highest socio-economic brackets, as it has in other settings.

The other component of the time tradeoff of interest in this analysis is leisure time. Leisure time has been used in time-use research as a measure of women's wellbeing (Shin 2013). Much less is known about leisure time availability in non-Western countries. In the United States, women have less leisure time than men, due primarily to doing more unpaid (household) work (Bianchi et al. 2000; Sayer 2005). Caregiving for children has been shown to reduce women's leisure time in the United States: therefore it is possible that caregiving for aging parents could also reduce women's leisure time (Kimmel and Connelly 2007). There is no known literature on how caregiving for aging parents affects the work/leisure balance in Egypt. Past work on labor supply in Egypt shows that the standard labor-leisure tradeoff model applies. When offered higher wages, Egyptians will substitute more work for less leisure (El-Hamidi 2003). Therefore, we hypothesize that similar trade-offs between labor time, leisure time, and household care responsibilities as found in other countries will also exist for Egyptian women.

\subsection{Conceptual model and measures}

The aim of this analysis is to explore the relationship between co-residing with a mother-in-law, the mother-in-law's disability status, and her daughter-in-law's work and leisure time (Figure 1). 


\section{Figure 1: Conceptual framework (MIL=Mother-in-law)}

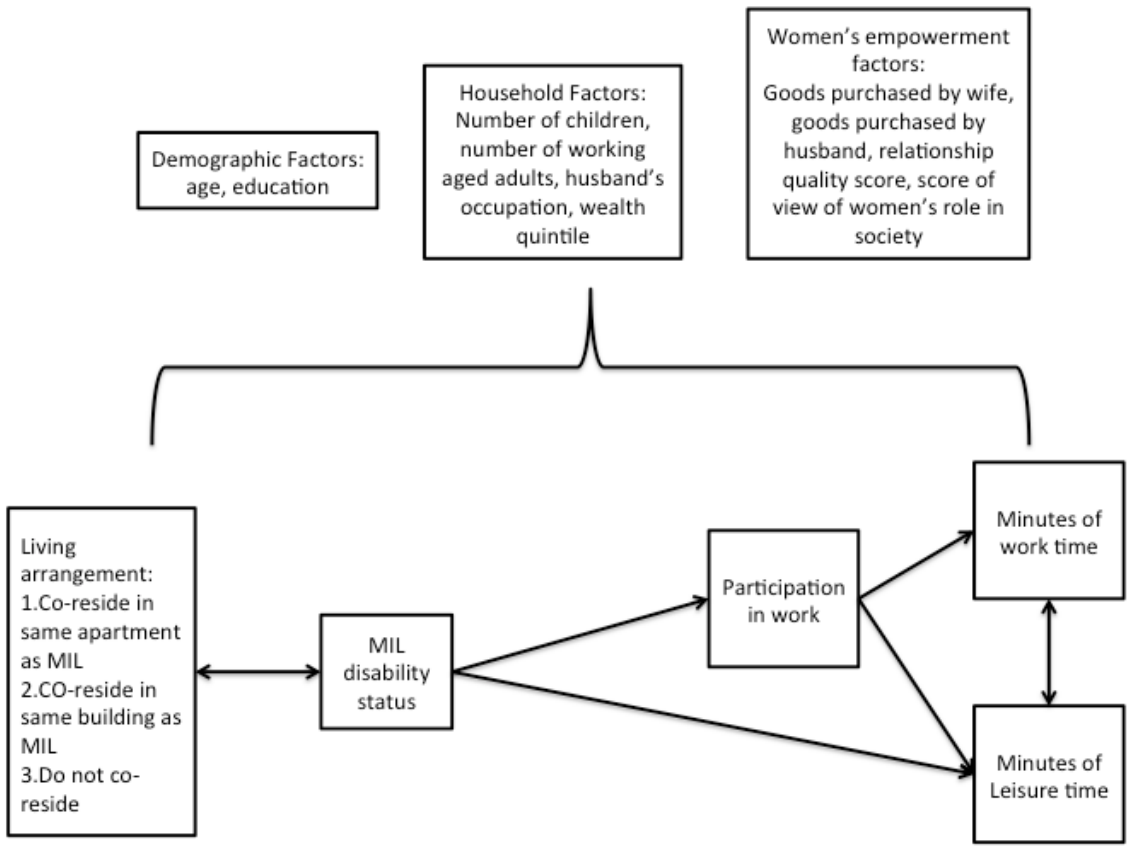

As can be seen in Figure 1, we hypothesize that a woman's living situation and the disability status of her mother-in-law are associated with whether she has worked in the last three months, for how much time in a day, and how much leisure time she has in a day. Time spent in work and leisure interact with each other (since there is a time tradeoff).

We hypothesize that demographic and household factors are associated with both having worked in the last 3 months, and minutes of work and leisure time, including women's age and education, husband's occupation, household wealth, and the number of children under 16 and number of adults 16-64 in the household. These last two variables are meant to capture the burden of caring for children and the number of other adults in the household who might contribute, either by working or sharing in the caretaking of children or the elderly.

We also hypothesize that factors related to women's empowerment, including her relationship with her husband and her own view of the status of women, could be associated with both whether or not she is co-residing with her mother-in-law and whether she is working. We hypothesize that more-empowered women are more likely 
to work outside the home and less likely to live with a mother-in-law. We have conceptualized empowerment based on the theoretical model proposed by Mason and colleagues, which focuses in the domestic sphere, as does this research (Mason 2005). Their theoretical model assumes that empowerment is founded in social/cultural norms and beliefs and is multidimensional. Much past literature has explored the many dimensions that can be measured to understand empowerment, including concepts such as power, autonomy, status, agency, mobility, decision-making power, etc. (Hindin 2000; Roushdy 2004; Upadhyay and Karasek 2012).

We use three separate measures of different aspects of empowerment in this analysis. First, to measure dimensions of empowerment related to social/cultural norms, we use a series of questions from the Demographic and Health Surveys revolving around acceptability of wife beating, inequality in relationships, gender preferences, etc., as have been used by numerous scholars to measure women's empowerment (Linos, Khawaja, and Al-Nsour 2010; Upadhyay and Karasek 2012). Second, we use questions about couples' relationship quality, including partner communication, and marital relationship quality, to address another dimension of empowerment related to couples' dynamics and decision-making. These measures have been used to measure the association between women's empowerment and decision-making and contraceptive use (Muntifering Cox et al. 2013). Finally, we include measures of ownership of household resources, specifically the number of goods that the husband and wife each brought into the household at the time of marriage. Past research in Egypt has found that the relative shares of pre-marriage assets contributed to the marriage by the husband and the wife were associated with child schooling and child labor supply (Namaro and Roushdy 2009; Roushdy and Namaro 2007). Higher relative contributions to the marriage by women compared to men appear to strengthen women's bargaining and decision-making power in the Egyptian context.

There are many ways to measure work, formal work, non-formal work, and leisure time. Research in Egypt has found that lists asking about participation in a set of possible activities are a good way to measure various types of women's work, as opposed to simply asking if someone works in the labor market (Langsten and Salem 2008). Activity lists allow women to identify various types of work that they do, thereby offering a fuller picture of the nature of the work. For this paper we use women's self identification through the question "Did you participate in any employment during the past three months?" in one model, and then in the time-use model we use a continuous variable from the time-use data including the minutes of time that women said they had worked in "income-generating activities", "at work", and "commuting to work" (chosen from an activity list). There is very little research on leisure time for women in Egypt or the MENA region, and therefore little past literature about how to best conceptualize leisure in this setting. Hence, items from the activities 
list that were not related to work of any type or to expected social, cultural, or religious obligations (such as praying) are conceptualized as "leisure time". This included activities such as watching TV, listening to music, visiting with friends, etc.

\section{Data and methods}

\subsection{Data}

Study Site: This study was conducted in El Walideya, a semi-urban community just outside of Assiut, in Upper Egypt, with a total population of approximately 64,000 inhabitants (Census of Egypt 2006). The Central Agency for Public Mobilization and Statistics (Census Office in Egypt, CAPMAS) divides this sector into 3 more or less equal parts in population size: El Walideya South, Middle, and North. This study recruited respondents from El Walideya Middle, with a population of 24,023 living in 5,663 families/households (Census of Egypt 2006). The housing stock is mainly threeand four-storey walk-up apartments with one to two apartment units per storey.

In 2009 we recruited the CAPMAS personnel to update their enumeration and listing of household members in El Walideya Middle prior to conducting the study, so as to have an estimate of how many mothers-in-law would be co-residing. Mother-inlaw co-residence was defined as either co-residing with a mother-in-law in the same apartment unit or with a mother-in-law in the same building (but not the same apartment unit). In this part of Egypt, extended families will often live in one building with multiple apartments, so that aging parents might live in one apartment and their son and his family (or multiple sons and their families) might live in other apartments in the same building. Hence, there are many households in our sample that include multiple sisters-in-law (respondents) who share a mother-in-law living in the same building. For the remainder of the paper, the term "household" is used to describe this complex family unit that might span multiple families sharing an apartment or building. The sector selected for the study included streets numbered 1-65 out of 180 streets enumerated by CAPMAS. Digital maps of El Walideya from the 2006 census were used to identify the boundaries of each division. Data collection took place between April and June 2010.

Sampling: There were two different types of household from which we wanted to recruit respondents: households with 1) a co-residing mother-in-law and daughter-inlaw, or 2) a daughter-in-law not co-residing but whose mother-in-law was still alive. The target was to interview 250 co-residing daughters-in-law and their mothers-in-law (250) and 250 non co-residing daughters-in-law. Enumeration of the households in the study site listed 1,860 households, of which 1,055 had an eligible woman (age 15-49 
years of age, currently married, and with a living mother-in-law). In addition to the daughters-in-law, the sampling frame listed a total of 278 mothers-in-law co-residing with their daughters-in-law (27\% of all women aged $50+$ in the study sector). Out of the 278 mothers-in-law in the study area, 250 were successfully interviewed. If a motherin-law had more than one daughter-in-law co-residing, a maximum of 3 daughters-inlaw were randomly chosen and invited to participate. The presence of more than one daughter-in-law for each mother-in-law was common, with 32.7\% of mothers-in-law having more than one daughter-in-law also in the sample. Out of the 419 co-residing daughters-in-law, 291 were successfully interviewed.

Women completed household rosters and questionnaires about basic demographic status, birth histories, relationship quality, how much their mother-in-law helped them in household tasks, and family assets. Additionally, women completed a 24-hour timediary that included information about who was in the room with them, what they were doing, and how long they spent in each activity. Interviewers reviewed every diary and filled in missing data with the respondent. Women could record up to four activities per time period and up to four people in the room with them (husband, children/child, mother-in-law, other).

Co-residing mothers-in-law filled out a questionnaire that included basic demographic questions, as well as questions about her reason for living with her son, her beliefs and desires concerning grandchildren, and how much she helped out her daughter-in-law around the house. She was also asked a set of questions taken from the World Health Organization Disability Assessment Schedule (WHODAS 2.0, shortened version) (Üstün et al. 2010) about six domains of health and disability, including cognition, mobility, self-care, getting along, life activities (household and work), and social participation. Demographic and disability data on fathers-in-law or the respondent's own parents were not collected.

Questionnaires for both the daughters-in-law and their mothers-in-law were read out loud to the respondent by a female data collector, and filled in by the data collector to account for the possibility that some respondents might be illiterate. There was no compensation offered to respondents. However, the study team offered referrals for free medical examinations to all respondents. These included nutritional status assessment, tests for diabetes and hypertension, and bone mineral density assessment for diagnosis of osteoporosis. The study team rented a room and set up a clinic during the data collection, serviced by a general practitioner and a nurse. Women who were identified as having health problems were referred to Assiut University hospital for follow-up. 


\subsection{Variable construction}

The three main outcomes of interest explored in these models were (a) a woman saying that she was employed in the last three months (b) minutes spent working in incomegenerating activities, and (c) minutes spent in leisure time. The first outcome was a dichotomous variable of whether the respondent said they were employed in the last 3 months. The second two outcomes used data from the time diary to create sums of the minutes spent in the two activities. Work time was calculated by adding together the time the respondent said they spent "at work", "commuting to work", and in "incomegenerating activities" in a day, regardless of other activities listed in that time period. Time diary information was broken down into pure leisure time and non-leisure time. Pure leisure time was time spent doing a single activity or a combination of activities designated as leisure and could not be a combination of a leisure activity with a nonleisure activity. The designation of activities coded as leisure aimed to isolate activities that were not related to housework, childcare, senior-care, or labor force participation in this specific cultural context. A variable of pure leisure time was calculated as the total sum of all time spent only in unmitigated leisure time per 24-hour period. Since women could list a number of activities per time period, if she listed more than one activity in a time period the total sum of her time use in "leisure" or "work" could add up to more than 24 hours in a day.

The main predictor was a set of dummy variables categorizing mother-in-law disability status by co-residence status. Disability status of the mother-in-law was based on the WHODAS (Üstün et al. 2010). A total disability score was calculated and a binary variable was constructed where mothers-in-law with a disability score over 20 were classified as disabled (this represented the $75^{\text {th }}$ percentile). The comparison group is non-co-residing women, compared to women co-residing with a non-disabled mother-in-law and those co-residing with a disabled mother-in-law.

In each model we included demographic variables about the respondent, including age and years of school. To account for the role of husband's occupational status, we included a dummy for husband's occupational status being professional or high executive and another dummy for husband being retired, with the reference categories being other than high executive or other than retired, respectively. Number of children under 16 living in the household and number of adults 16-49 living in the household were included to control for the potential burden of childcare and the availability of other household members who might be able to help with childcare. Alternative models were also run with children under 5 instead of children under 16, with the hypothesis that children under 5 might require more caregiving time than children under 16; however, there was no difference in the models, and thus only the former was included. Unfortunately, the study population was all from one small community, so there is no variation in women's wages offered by the market. Consequently, we could not account 
for wage variation in the model. We included a variable for household wealth, in the form of dummy variables, for 5 wealth quintiles, based on the first principal component of household assets, with the reference category set to be the wealthiest quintile.

We also included a set of variables related to the respondent's view of women's roles, her contribution to household goods at the time of marriage, and her relationship quality. Marital relationship quality was a score based on a set of questions about trust and commitment within the marriage. Answers to the marital relationship quality questions were on a scale of 1-7 (Strongly Agree to Strongly Disagree) or 1-6 (Never to All of the Time), depending on the question. The scales of the questions were adjusted so that answers that denoted a high quality relationship had high scores and those that reflected low quality relationship had low scores. The summary score ranged from -36 to positive 46 . A second set of variables was constructed as a summary of the number of goods that the husband and wife each brought into the house at the time of marriage (one variable for the number of items the husband brought and one for number of items the wife brought). This information was based on a series of questions about household assets, where the respondent was asked to identify whether she or her husband had brought each item into the household at the time of marriage. Finally, the respondent answered 11 questions regarding the role of women, such as whether a woman's place is in the home, if a woman can both work and be a good mother, if girls and boys should have the same amount of schooling, etc. Respondents could answer all the questions on a scale of 1-5 (Strongly Agree to Strongly Disagree), except for the first question, which had a yes/no answer. A variable was created as a score based on these questions. We summed the answers, reversing the numbering of the answers to ensure that the more conservative views were coded with high numbers and the more liberal views with low numbers.

Additionally, we explored perceptions of household help from the mother-in-law's and the daughter-in-law's perspectives. Mothers-in-law were asked a set of questions about how much they helped around the house (for example, how often does she do laundry for her daughter-in-law or prepare meals when her daughter-in-law is out). Daughters-in-law were also asked questions about how much their mothers-in-law helped around the house (about similar topics like helping with laundry or meals). We made a score for the mother-in-law's perspective and the daughters-in-law's perspective on how much they/the other helped. The scores for women and mothers-in-law are based on a series of questions asked to each and the answer choices were structured differently for women and their mothers-in-law (never/sometimes/always for the mothers-in-law and yes/no for the women): hence the ranges are different. 


\subsection{Methods}

We appeal to a standard household decision-making model of labor supply where husbands and wives maximize a joint household utility function depending on husband and wife's consumption $c_{h}$ and $c_{w}$ as well as their leisure $l_{h}$ and $l_{w}$ (Becker 1981; Gronau 1973). Thus they maximize $\mathrm{U}\left(\mathrm{c}_{\mathrm{h}}, \mathrm{c}_{\mathrm{w}}, \mathrm{l}_{\mathrm{h}}, \mathrm{l}_{\mathrm{w}}\right)$. The goods they consume are $\mathrm{a}$ combination of home-produced and purchased goods and they are acquired by deploying their non-leisure time $\left(\mathrm{T}-\mathrm{l}_{\mathrm{i}}\right)$ in production efforts according to gendered production functions $g_{h}\left(T-l_{h}, w_{h}\right)$ and $g_{w}\left(T-l_{w}, w_{w}\right)$, where $T$ is 24 hours in a day, and $g_{h}$, $\mathrm{g}_{\mathrm{w}}$ are the production functions. The production functions include an exogenous term $\mathrm{w}_{\mathrm{h}}$ and $\mathrm{w}_{\mathrm{w}}$ for husband's and wife's wage respectively. If they pool their products, the household budget equation is $\left(c_{h}+c_{w}\right)=g_{h}\left(T-l_{h}, w_{h}\right)+g_{w}\left(T-l_{w}, w_{w}\right)$. This simple model predicts specialization or production in either market goods or domestic goods according to each partner's productivity. Where husband's wages are higher than wife's wages we expect relatively more labor supply by the husband. In this context the insertion of a third person in the form of a mother-in-law who has skills and expectations of supplying domestic goods might shift the balance, allowing the wife to supply more labor. However, if the mother-in-law's disabilities make them a net drain on domestic labor, then the wife would supply less labor.

We were interested in the effects of mother-in-law co-residence on both parts of a two-part decision: 1) the decision to work, and subsequently 2) for those who work, the decision over how many hours of work to supply. We are concerned that the mother-inlaw's presence may be endogenously determined by both labor supply decisions. The reasons any given household (household could include the whole building with different co-residing related family members) has its current members will be bound up with pre-existing choices on labor supply, making it difficult to infer that it is the mother-in-law's presence that is the causal driver. There are few variables that predict household structure but have no direct effect on labor supply. Past scholars have asserted that the adult's number of siblings might predict co-residence with a disabled senior parent or in-law but could be excluded from directly predicting her labor supply (Johnson and Lo Sasso 2006). Similarly, the adult's number of own children has been held to predict labor supply, but not co-residence with a disabled senior (Johnson and Lo Sasso 2006). We explored these options, but found that, based on the F-test, neither the birth order of the husband nor husband's number of siblings was a strong enough predictor of mother-in-law co-residence to serve as an instrument. Consequently, our findings on the relationship between co-residence and time use reflect potentially endogenous effects, and we will not claim that these household structures are causing the labor supply patterns that are observed. 
(i) Estimating Dichotomous Labor Supply

We estimate equation [1] with a logistic regression model.

$\operatorname{Pr}\left(\right.$ Labor Supply $\left._{\mathrm{it}}>0\right)=\mathrm{C}_{1}+\beta_{1}\left(\right.$ Mother-in-law $\left._{\mathrm{i}}\right)+\beta_{2} \mathrm{X}_{\mathrm{it}}+\beta_{3}\left(\right.$ Number of $\left.\left._{\text {children }}\right)+\llbracket 1\right]$

where $\mathrm{C}_{1}$ is a constant, $\mathrm{X}_{\mathrm{it}}$ is a vector of covariates measured for each household at each time point, $\beta_{1}, \beta_{2, \text {, and }} \beta_{3}$ are coefficients, and $\varepsilon_{\mathrm{it}}$ is the error term of the i-th woman at time t.

(ii) Estimating Models of Time Use: labor and leisure

We estimate [2] using a tobit model for labor hours and an ordinary least squares model for leisure time.

Minutes worked $_{\mathrm{it}}=\mathrm{C}_{2}+\beta_{1}\left(\right.$ Mother-in-law $\left._{\mathrm{i}}\right)+\beta_{2} \mathrm{X}_{\mathrm{it}}+\beta_{3}\left(\right.$ Number of children $\left._{\mathrm{i}}\right)+\mathbb{T} \mathbb{R}$ ]

Only a subset of women said that they had worked in the last three months and $77 \%$ of our sample women reported zero minutes spent working on the day of time diary data collection. A Tobit model of the number of minutes of labor supply was an effective way to handle the large number of zeros. In separate analysis we also implemented a Heckman model, but the results are similar to the Tobit and we do not present the Heckman results here. Truncated and censored models were not necessary to estimate leisure time because only $7.3 \%$ of women reported no pure leisure time.

\subsection{Robustness tests}

First each model was run with only the variables related to co-residence with mothersin-law and disability status. We then added our demographic, household (number of children under 16, number of adults, and whether father-in-law was alive), and variables relating to women's empowerment (goods brought into the household at marriage by the husband and wife, the score of liberalness, and relationship quality). We also ran a robustness test with mother-in-law disability measured as a continuous variable (rather than a categorical cut-off at the $75 \%$ percentile) (not shown). We also ran all models with a more stratified variable for mother-in-law co-residence status and disability, since some women lived in the same apartment, and some in the same building as their mothers-in-law. This model did not differ substantially from the more parsimonious model, shown here. 


\section{Results}

\subsection{Characteristics of daughters-in-law and their mothers-in-law}

Daughters-in-law in the sample were on average 31 years old, and there was a statistically significant $(\mathrm{p}<0.01)$ age difference between co-residing and non-co-residing women, with co-residing women being older (Table 1). There were also significant differences between the women co-residing with disabled and non-disabled mothers-inlaw, with women co-residing with disabled mothers-in-law being older. Related to the age difference, non-co-residing women lived with more children under 16 than coresiding women, and they had more children ( $\mathrm{p}<0.01$ for both). Women co-residing with disabled mothers-in-law also had more children than women co-residing with nondisabled mothers-in-law. The full sample of daughters-in-law had on average 2.57 children. It is important to highlight that the fertility rates of the daughters-in-law are not necessarily completed fertility rates, because many of the women were still in childbearing years. The majority of daughters-in-law had completed 12 or more years of schooling and there was no schooling difference between co-residing and non-coresiding women. Regardless of co-residence status, more women lived in households with 1-2 women than in households with 3 or more in all groups. Of non-co-residing women, $33 \%$ were working whereas $26 \%$ of those living with non-disabled and $18 \%$ of those co-residing with disabled mothers-in-law were working $(\mathrm{p}<0.05)$. Women who were not co-residing spent significantly more minutes working (103 compared to 72 and 57 in the non-disabled and disabled groups respectively). Women who were not coresiding spent fewer minutes in leisure (218 compared to 259 and 241 in the nondisabled and disabled groups respectively). There was no difference in the percentage of daughters-in-law who had living fathers-in-law. There was no difference in the mean of the assets score between the two groups of women. 
Table 1: Demographic characteristics of women of reproductive age (respondents).

\begin{tabular}{|c|c|c|c|c|}
\hline & \multicolumn{3}{|l|}{ Daughters-in-Law } & \multirow{2}{*}{$\begin{array}{l}\text { Mothers-in-law } \\
\text { Mothers-in-law } \\
\mathrm{N}=250, \mathrm{~N}(\%)\end{array}$} \\
\hline & $\begin{array}{l}\text { Non co-residing } \\
\text { women } \\
\mathrm{N}=257 \mathrm{~N}(\%)\end{array}$ & $\begin{array}{l}\text { Co-residing women with } \\
\text { non-disabled MIL } \\
\mathrm{N}=229 \mathrm{~N}(\%)\end{array}$ & $\begin{array}{l}\text { Co-residing women } \\
\text { with disabled MIL } \\
N=62 N(\%)\end{array}$ & \\
\hline \multicolumn{5}{|l|}{ Age in years } \\
\hline \multicolumn{5}{|l|}{ Daughters in Law/ } \\
\hline \multicolumn{5}{|l|}{ Mothers-in-law } \\
\hline$<20 /<50$ & $3(1.2)^{\star \star \star}$ & $6(2.6)^{+++}$ & $1(1.6)$ & $19(7.6)$ \\
\hline 20-29/50-59 & $96(37.4)$ & $113(49.4)$ & $13(21.0)$ & $70(28.0)$ \\
\hline $30-39 / 60-69$ & $107(41.6)$ & $69(30.1)$ & $25(40.3)$ & $85(34.0)$ \\
\hline$>=40 / 70+$ & $51(19.8)$ & $41(17.9)$ & $23(37.1)$ & $76(30.3)$ \\
\hline \multicolumn{5}{|l|}{$\begin{array}{l}\text { Total number of children under } 16 \\
\text { in household }\end{array}$} \\
\hline 0 & $23(9.0)^{\star \star \star}$ & $33(14.4)$ & $7(11.3)$ & \\
\hline $1-2$ & $119(46.3)$ & $126(55.0)$ & $29(46.8)$ & \\
\hline $3-4$ & $98(38.1)$ & $61(26.6)$ & $23(37.1)$ & \\
\hline $5+$ & $17(6.6)$ & $9(3.9)$ & $3(4.8)$ & \\
\hline \multicolumn{5}{|l|}{ Total number of children ever born } \\
\hline \multicolumn{5}{|l|}{0} \\
\hline $1-2$ & $18(7.0)^{\star \star \star}$ & $32(14.0)^{+++}$ & $6(9.7)$ & $3(1.2)$ \\
\hline $3-4$ & $100(38.9)$ & $112(48.9)$ & $19(30.7)$ & $20(8.0)$ \\
\hline $5+/ 5-8$ & $106(41.3)$ & $65(28.4)$ & $24(38.7)$ & $154(61.6)$ \\
\hline $9+$ kids & $33(12.8)$ & $20(8.7)$ & $13(21.0)$ & $72(29.2)$ \\
\hline \multicolumn{5}{|c|}{$\begin{array}{l}\text { Total number of adult women in the } \\
\text { household } 16-64\end{array}$} \\
\hline \multicolumn{5}{|l|}{ 1-2 adult women } \\
\hline \multirow[t]{2}{*}{$>2$ adult women } & $145(56.4)$ & $134(58.5)$ & $44(71.0)$ & \\
\hline & $112(43.6)$ & $95(41.5)$ & $18(29.0)$ & \\
\hline \multicolumn{5}{|l|}{ Educational Status } \\
\hline None & $23(9.0)$ & $26(11.4)$ & $8(12.9)$ & $141(48.6)$ \\
\hline $1-5$ years & $16(6.2)$ & $14(6.1)$ & $6(9.7)$ & $90(31.0)$ \\
\hline 6-11 years & $83(32.3)$ & $70(30.6)$ & $15(24.2)$ & $45(15.5)$ \\
\hline 12 years & $85(33.1)$ & $59(25.8)$ & $25(40.3)$ & $12(4.1)$ \\
\hline More than 12 years & $50(19.5)$ & $60(26.2)$ & $8(12.9)$ & $2(0.7)$ \\
\hline $\begin{array}{l}\text { Participated in labor force in past } 3 \\
\text { months (Yes) }\end{array}$ & $85(33.1)^{\star *}$ & $59(25.8)$ & $11(17.7)$ & \\
\hline $\begin{array}{l}\text { Time spent in work (income } \\
\text { generating) (mean minutes per } \\
\text { day) }\end{array}$ & $102.7^{\star \star}$ & 71.8 & 57.3 & \\
\hline Pure Leisure time (mean minutes & & 259.1 & 240.7 & \\
\hline per day) & $218.4^{\star \star \star}$ & & & \\
\hline Father-in-law alive & $121(47.1)$ & $136(59.4)^{+++}$ & $20(32.3)$ & \\
\hline \multicolumn{5}{|l|}{ Wealth Quintile } \\
\hline Poorest & $54(21.0)$ & $43(18.8)$ & $14(22.6)$ & \\
\hline Second Poorest & $51(19.8)$ & $48(21.0)$ & $9(14.5) \quad 16(25.8)$ & \\
\hline Middle & $38(14.8)$ & $55(24.0)$ & $14(22.6)$ & \\
\hline Second Richest & $54(21.0)$ & $43(18.8)$ & & \\
\hline Richest & $60(23.4)$ & $40(17.5)$ & & \\
\hline Disabled & & & & $62(21.3)$ \\
\hline
\end{tabular}

${ }^{\star \star} \mathrm{p}<0.05,{ }^{* \star \star} \mathrm{p}<0.01$

Stars/crosses indicate t-tests between the groups of daughters-in-law. Stars show difference between co- residing and non-coresiding, and crosses show difference between those co-residing with disabled and non-disabled MIL 
The majority of mothers-in-law were 60-79 years old, and almost two-thirds had five to eight children (Table 1). About half of mothers-in-law (49\%) had no schooling, with about 5\% having completed at least 12 years of school. Twenty-one percent of mothers-in-law were disabled.

The hourly time-use data provide a snapshot of what the daily life of married women in peri-urban Egypt is like. Only 23\% of women spent time in incomegenerating or work activities, and among these women the average number of minutes worked per day was 368 (or about 6 hours) (data not shown). Women spent 19 minutes praying, about an hour on social activities, and over 2 hours watching TV. Women spent one and a half hours caring for children, and two and a half hours preparing food (Table 2).

Table 2: Amount of time in the main activities in which women spend their time in a day, collected in the time use diary

\begin{tabular}{lcr}
\hline Activity & Mean time per Day (minutes) & SD \\
\hline Sleep & 499 & 137 \\
Praying & 19 & 44 \\
Working & 78 & 160 \\
Food Preparation & 155 & 86 \\
Caring for children & 94 & 177 \\
Social Activities & 61 & 112 \\
TV Watching & 125 & 110 \\
\hline
\end{tabular}

Table 3 shows details of the amount of time women spent working in household tasks by the age of the mother-in-law, and compared to non-co-residing women. It also shows a score for how often the woman said her mother-in-law helped her and how often the mother-in-law said that she helped the woman, by the age of the mother-inlaw. Women who did not live with a mother-in-law spent more time in household work than women who did live with a mother-in-law, on average. We also see evidence of a trend where women with a younger mother-in law spent less time doing household tasks, although when childcare is included as a household task the trend is not linear. Both mothers-in-law and daughters-in-law rated mothers-in-law as helping out less with household tasks when the mother-in-law was older. Women who did not live with their mothers-in-law reported the least amount of help from their (non-resident) mothers-inlaws. 
Table 3: Daughter-in-law's time spent in household tasks and mother-in-law's help in the household, by mother-in-law age group

\begin{tabular}{|c|c|c|c|c|}
\hline & $\begin{array}{l}\text { Daughter-in-law's } \\
\text { TOTAL minutes } \\
\text { Spent in Domestic } \\
\text { Work, not Including } \\
\text { Childcare (Mean, } \\
\text { range) }\end{array}$ & $\begin{array}{l}\text { Daughter-in-law's } \\
\text { TOTAL minutes } \\
\text { Spent in Domestic } \\
\text { Work, Including } \\
\text { Childcare** (Mean, } \\
\text { range) }\end{array}$ & $\begin{array}{l}\text { Mother-in-law's } \\
\text { views of how much } \\
\text { she helps in the } \\
\text { household (score 1- } \\
\text { 13), Mean } \\
\text { (Standard Deviation) }\end{array}$ & $\begin{array}{l}\text { Daughter-in-law's views } \\
\text { of how much her } \\
\text { mother-in-law helps in } \\
\text { the household (score 1- } \\
\text { 8), Mean } \\
\text { (Standard Deviation) }\end{array}$ \\
\hline \multicolumn{5}{|l|}{ Mother-in-law } \\
\hline$<50$ & $251(0-585)$ & $314(0-705)$ & $6.3(4.1)$ & $5.0(1.7)$ \\
\hline $50-59$ & $264(0-645)$ & $356(0-820)$ & $5.4(3.3)$ & $4.3(1.4)$ \\
\hline $60-69$ & $290(0-800)$ & $414(0-1545)$ & $5.4(2.8)$ & $4.1(1.2)$ \\
\hline $70+$ & $308(0-775)$ & $363(0-1135)$ & $5.1(2.7)$ & $4.0(1.3)$ \\
\hline $\begin{array}{l}\text { Non-Co-Resident } \\
\text { daughters-in-law }\end{array}$ & $307(0-825)$ & $438(0-1560)$ & & $3.3(0.8)$ \\
\hline
\end{tabular}

\subsection{Odds of having worked in the last three months (Table 4)}

Co-residing with a non-disabled mother-in-law was significantly associated with lower odds (OR=0.7) of having worked in the last three months at the $\mathrm{p}<0.1$ level, but it lost significance after controlling for other covariates. Co-residing with a disabled motherin-law was associated with reduced odds $(\mathrm{OR}=0.3, \mathrm{p}<0.01)$ of having worked in the last three months after controlling for other variables. The woman being older $(\mathrm{OR}=1.1$, $\mathrm{p}<0.01)$ and having more education $(\mathrm{OR}=2.1, \mathrm{p}<0.01)$ was associated with increased odds of having worked in the last three months, and being in the poorest $(\mathrm{OR}=0.3$, $\mathrm{p}<0.01$ ) or second poorest $(\mathrm{OR}=0.5, \mathrm{p}<0.1)$, compared to the richest wealth quintile was associated with decreased odds of having worked in the last three months. Living in a house with more children under the age of 16 was associated with decreased odds of having worked in the last three months $(\mathrm{OR}=0.8, \mathrm{p}<0.05)$. The woman bringing more goods into the household at the time of marriage was associated with increased odds of having worked in the last three months $(\mathrm{OR}=1.7, \mathrm{p}<0.05)$, and the husband bringing in more goods at the time of marriage was associated with lower odds $(\mathrm{OR}=0.5, \mathrm{p}<0.01)$. Having a less liberal view of women's status $(\mathrm{OR}=1.0, \mathrm{p}<0.05)$ and having a better relationship quality score $(\mathrm{OR}=1.0, \mathrm{p}<0.01)$ were associated with lower odds of having worked in the last three months. None of the other variables were significant. 
Table 4: Odds of having worked in the past three months, odds ratio [tstatistic]

\begin{tabular}{|c|c|c|}
\hline & Bi-variate & Full \\
\hline Co-residing mother-in-law, not disabled [1] & $0.7^{*}[-1.7]$ & $1.1[0.2]$ \\
\hline Co-residing mother-in-law, disabled [1] & $0.4^{\star \star}[-2.4]$ & $0.3^{\star \star \star}[-3.1]$ \\
\hline Age in years & & $1.1^{\star \star \star}[4.5]$ \\
\hline Education in Years & & $2.1^{\star \star \star}[4.5]$ \\
\hline Poorest wealth quintile [2] & & $0.3^{\star \star}[-2.1]$ \\
\hline Second poorest wealth quintile [2] & & $0.5^{\star}[-1.7]$ \\
\hline Middle wealth quintile [2] & & $0.9[-0.2]$ \\
\hline Second Richest wealth quintile [2] & & $1.3[0.7]$ \\
\hline $\begin{array}{l}\text { Husband's Occupation: Executive, professional with high } \\
\text { degree [3] }\end{array}$ & & $1.4[1.2]$ \\
\hline Husband's Occupation: Retired [3] & & $7.3[1.6]$ \\
\hline Husband's years of schooling & & $1.1[1.6]$ \\
\hline Number of adult women in the $\mathrm{HH}$ & & $0.9[-0.7]$ \\
\hline Number $<16$ in Household & & $0.8^{\star \star}[-2.0]$ \\
\hline Number of adults $15-64$ in household & & $0.8[-1.4]$ \\
\hline Father-in-law is alive & & $1.0[-0.1]$ \\
\hline Number goods wife brought into household at marriage & & $1.7^{\star \star}[2.0]$. \\
\hline $\begin{array}{l}\text { Number goods husband brought into the household at } \\
\text { marriage }\end{array}$ & & $0.5^{\star \star \star}[-2.6]$ \\
\hline Non-liberal view of women's role score & & $1.0^{\star \star}[-2.3]$ \\
\hline Relationship quality score & & $1.0^{\star \star \star}[-2.8]$ \\
\hline Constant & $0.5^{\star \star \star}[-5.3]$ & $0.1[-1.6]$ \\
\hline Observations & 548 & 478 \\
\hline Pseudo R-squared & 0.0 & 0.3 \\
\hline
\end{tabular}

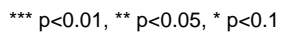

[1] Reference group: Not co-residing [2] Reference group: wealthiest wealth quintile [3] Reference group: husband's occupation other than Retired or Executive/professional with high degree

\subsection{Minutes of time spent in work activities (Table 5)}

Co-residing with a non-disabled mother-in-law was associated with fewer minutes spent in work activities (minutes $=-126.7, \mathrm{p}<0.05$ ) in the bivariate model; however, it lost significance after controlling for other variables. Co-residing with a disabled mother-inlaw was associated with fewer minutes in both the bivariate and full models (full: minutes=-300.0, $\mathrm{p}<0.01$ ). Women being older and having more education were associated with more minutes spent in work activities (24.45, $\mathrm{p}<0.01$ and 164.1, $\mathrm{p}<0.01$ ), respectively). Having a retired husband, compared to a working husband, was 
associated with more minutes spent in work activities $(464.6, \mathrm{p}<0.05)$. Being a woman whose husband brought more goods into the household and who had a more liberal view of women's role was associated with fewer minutes spent in work activities $(-121.6, \mathrm{p}<0.05$ and $-13.14, \mathrm{p}<0.05$, respectively). None of the other variables were significantly associated.

\section{Table 5: Tobit model of mother-in-law co-residence and disability status on number of minutes a day spent working in income-generating activities, coefficient [t-statistic]}

\begin{tabular}{|c|c|c|}
\hline & Bi-variate & Full \\
\hline Co-residing mother-in-law, not disabled [1] & $-126.7^{\star \star}[61.2]$ & $-31.1[58.3]$ \\
\hline Co-residing mother-in-law, disabled [1] & $-226.5^{\star \star}[106.2]$ & $-300.0^{\star \star \star}[103.7]$ \\
\hline Age in years & & $24.5^{\star \star \star}[4.9]$ \\
\hline Education in Years & & $164.1^{\star \star \star}[37.4]$ \\
\hline Poorest wealth quintile [2] & & $-193.6[145.5]$ \\
\hline Second poorest wealth quintile [2] & & $-127.2[116.8]$ \\
\hline Middle wealth quintile [2] & & $23.9[99.6]$ \\
\hline Second richest wealth quintile [2] & & $20.7[78.0]$ \\
\hline Husband's Occupation: Executive, professional with high degree [3] & & $119.2[77.2]$ \\
\hline Husband Occupation: Retired[3] & & $464.6^{\star \star}[235.8]$ \\
\hline Husband's years of schooling & & 14.8 [13.2] \\
\hline Total number of adult women in the household & & $-9.7[24.6]$ \\
\hline Number $<16$ in Household & & $-15.2[27.00]$ \\
\hline Number of adults $15-64$ in household & & $-30.6[36.4]$ \\
\hline Father-in-law is alive & & $-57.2[59.3]$ \\
\hline Number goods wife brought into household at marriage & & 84.9 [61.2] \\
\hline Number goods husband brought into the household at marriage & & $-121.6^{\star \star}[59.2]$ \\
\hline Non-liberal view of women's role score & & $-13.1^{\star \star}[5.7]$ \\
\hline Relationship quality score & & $-3.6[2.3]$ \\
\hline Constant & $-296.2^{\star \star \star}[52.1]$ & $-709.5^{\star}[413.2]$ \\
\hline Sigma & $531.0^{\star \star \star}[22.7]$ & $429.4^{\star \star \star}[27.7]$ \\
\hline Observations & 548 & 478 \\
\hline
\end{tabular}

*** $p<0.01,{ }^{\star *} p<0.05,{ }^{*} p<0.1$

[1] Reference group: Not co-residing [2] Reference group: wealthiest wealth quintile [3] Reference group: husband's occupation other than Retired or Executive/professional with high degree 


\subsection{Minutes of time spent in leisure (Table 6)}

Living with a non-disabled mother-in-law was associated with more minutes of leisure time in a day $(40.763, \mathrm{p}<0.05)$ in the bivariate model; however, it lost significance after controlling for other variables. Living with a disabled mother-in-law was not associated with minutes of leisure time in either model. Being a woman with more education or who lived in a house with more children under the age of 16 was associated with fewer minutes of leisure time $(-30.507, \mathrm{p}<0.01$ and $-21.330, \mathrm{p}<0.01$, respectively). None of the other variables were significantly associated.

Table 6: Ordinary least square regression of mother-in-law co-residence and disability status on number of minutes a day spent in pure leisure time, coefficient [t-statistic]

\begin{tabular}{|c|c|c|}
\hline & Bi-variate & Full \\
\hline Co-residing mother-in-law, not disabled [1] & $40.8^{\star \star}[2.6]$ & $25.5[1.5]$ \\
\hline Co-residing mother-in-law, disabled [1] & $22.3[1.1]$ & $24.4[1.1]$ \\
\hline Age in years & & $-0.4[-0.3]$ \\
\hline Education in Years & & $-30.5^{\star \star \star}[-2.9]$ \\
\hline Poorest wealth quintile [2] & & $37.00[1.0]$ \\
\hline Second poorest wealth quintile [2] & & $47.5[1.6]$ \\
\hline Middle wealth quintile [2] & & $5.9[0.2]$ \\
\hline Second richest wealth quintile [2] & & $3.1[0.1]$ \\
\hline Husband's Occupation: Executive, professional with high degree & & $13.0[0.7]$ \\
\hline [N1] Husband's Occupation: Retired[3] & & $-37.7[-0.9]$ \\
\hline Husband's years of schooling & & 0.9 [0.3] \\
\hline Total number of adult women in the household & & $3.0[0.5]$ \\
\hline Number $<16$ in Household & & $-21.3^{\star \star \star}[-3.3]$ \\
\hline Number of adults $15-64$ in household & & $9.9[1.1]$ \\
\hline Father-in-law is alive & & $-8.7[-0.5]$ \\
\hline Number goods wife brought into household at marriage & & $-16.4[-1.0]$ \\
\hline Number goods husband brought into the household at marriage & & $20.3[1.2]$ \\
\hline Non-liberal view of women's role score & & $1.0[0.6]$ \\
\hline Relationship quality score & & $0.8[1.23]$ \\
\hline Constant & $218.4^{\star \star \star}[20.6]$ & $223.5^{\star \star}[2.4]$ \\
\hline Observations & 548 & 478 \\
\hline R-squared & 0.0 & 0.1 \\
\hline
\end{tabular}

*** $p<0.01,{ }^{* \star} p<0.05,{ }^{*} p<0.1$

[1] Reference group: Not co-residing [2] Reference group: wealthiest wealth quintile [3] Reference group: husband's occupation other than Retired or Executive/professional with high degree 


\section{Discussion}

\subsection{Mothers-in-law, disability, household structure, and women’s work and leisure}

Co-residing with a disabled mother-in-law was associated with both lower odds of having worked in the last three months and fewer minutes spent working each day. Coresidence and disability status were not associated with leisure time in the full model. This suggests that mother-in-law co-residence can be negatively associated with labor supply, depending on the health of the mother-in-law.

Our findings support past literature that found that living with a mother-in-law can add more burdens to women's lives, and adds to this literature by showing differences by the disability status of the mother-in-law (Lane and Meleis 1991). We also found that women who co-reside spend less time in domestic work than non-co-residing women and women spend less time in household tasks when their mothers-in-law are younger. Co-residing with a mother-in-law in itself does not appear to be correlated with additional women's care-giving responsibilities: it is only when that mother-in-law is disabled that the burden appears to increase.

Life expectancies have been extending rapidly around the world, with women generally having longer life expectancies than men (although the gap is closing in some countries) (Oeppen and Vaupel 2002). There are competing views about the relationship between increasing life expectancy, disability, and morbidity (Fries 1980). One view predicts increasing life expectancy without morbidity reduction, so people will spend more time disabled. The opposing view is that the onset of disability will be pushed back as life expectancy is extended, so there will be a compression of the life span's period of morbidity, and people will spend more years healthy and a constant or reduced number of years disabled.

If increases in life expectancy lengthen co-residence periods in Egypt, our findings indicate divergent impacts on women's labor supply, depending on whether or not there is a compression of morbidity. If mothers-in-law experience more years of disability while co-residing with their daughters-in-law, we might see less labor force participation, less time spent working, and less leisure time for women of reproductive age. However, if mothers-in-law live longer in a healthy state, then women of reproductive age might have more help around the house for more years, improving their quality of life. All of this may be negated if increases in life expectancy lead couples to change their behavior regarding co-residence, and choose to shorten coresidence durations or not to co-reside at all when faced with the prospect of longer periods of co-residence.

By adding a variable for the number of adult women in the household or building, we controlled for the fact that some households/buildings had multiple daughters-in- 
law, and potentially other family members such as aunts and sisters, who could also provide household work and care for aging parents. The addition of this variable did not change the relationships of interest in this analysis, and it was not significantly associated with the main outcomes of interest.

Other household-level factors were associated with women's labor and leisure. Having more children under age 16 living in the household was associated with both decreased odds of having worked in the last three months and fewer minutes of leisure time in a day. These findings are not surprising, as we would expect that under Egyptian gender norms, having more children to care for is a competing use of time that crowds out labor force participation and leisure time. Past literature on the Arab world has also found that fertility has a negative effect on labor force participation (Al-Qudsi 1998; Hendy 2011). With changing demographic structures, the findings of this study suggest that lower fertility would give women more time for working; however, this could be counteracted by a reduction in the overall number of working-age adults in the household.

\subsection{Relationship between variables related to women's empowerment and work and leisure}

A higher score for having a non-liberal view of women's roles was associated with decreased odds of having worked in the last three months and fewer minutes per day spent working. The score relates to questions on the role of women in the workplace: therefore this suggests that attitudes towards women's role influence behaviors. It is also possible that views about the role of women are shaped by women's opportunities to participate in the labor force or other activities outside the home. Further research should disentangle the directionality of this association.

Past social survey research on gender equality attitudes around the world found that a large number of Egyptian respondents were comfortable with statements of gender inequality. Egypt stands out in this regard, even among conservative or predominantly Muslim countries. For example, only 10\% of people in Egypt disagreed with the statement "men make better political leaders than women", compared to about 25\% disagreeing in Iran and about 30\% disagreeing in Morocco (Inglehart and Norris 2003). Our findings suggest that expressing these types of gender values are statistically associated with lower odds of women working.

Women bringing a larger number of goods into the household at marriage was associated with increased odds of having worked in the last three months. Men bringing a larger number of goods into the household at marriage was associated with decreased odds of the woman working in the last three months and fewer minutes spent working. 
Bringing more goods to a marriage may simply indicate past labor productivity and foretell high returns and high labor supply in accordance with a simple theory of household time allocation. However, if working in the labor force is desirable for Egyptian women, then women's goods brought to a marriage might signify a better negotiating position and the use of this power to bargain for more opportunities to work.

Men bringing more goods into the household is associated with women being less likely to work in the labor force and working fewer minutes. Again, this may simply signify specialization of couples due to wage differentials. Alternatively, this could be a story of conflict, with men using their economic power to restrain wives' aspirations to work. The contextual meaning of goods brought into marriage is unclear and qualitative research should examine whether these variables measure labor productivity or decision-making power.

A higher score on the relationship quality measure (better relationship quality) was associated with reduced odds of women having worked in the last three months. This may suggest that women have a more positive view of their relationship when they are not working, or that in households where the couple has a better relationship, women are able to request to not work, assuming they do not want to. It is possible that in more 'conservative' or 'traditional' homes, where women are less likely to work, women also feel pressured to answer relationship quality questions in a more positive manner. Our findings suggest that there is an association between relationship quality and women's work, and more research into the direction of the causality of this association could help us understand the meaning of this finding.

\section{(a) Limitations}

El Walideya is typical of many areas in Egypt in which a former rural village has been transformed by the encroachment of a large nearby city. El Walideya represents only one semi-urban community in Upper Egypt, and therefore these results are not necessarily generalizable outside of this area, or outside of Egypt. We do not believe that the sampling strategy led to any systematic biases in representing the sample population. Some women and mothers-in-law refused to participate in the study, and it is possible that these women came from more conservative families that would not have been comfortable with them participating in a study. This would have biased the sample towards more liberal women, who might have been more likely to work outside the home. That so few women in the study worked outside the home, as has been found elsewhere in Egypt, suggests that our sample was not biased too much away from working women. 
The choice to co-reside is endogenous, and can simultaneously be determined by a woman's intention to supply labor. The cross-sectional nature of this study does not allow us to fully disentangle the causal direction of the relationship between in-law coresidence and women's labor supply. Our data did not have appropriate instrumental variables that could be defended. Similarly, we could not defend the assumptions required to use propensity scores, because the propensity to co-reside would depend heavily on unobservable factors. Instead, we will discuss the potential magnitude of the endogeneity bias. Every co-residing woman in our sample who lived with her motherin-law reported doing so for the whole time that she was married. This suggests that couples do not change co-residence status and co-residence may be an all-or-nothing choice for couples. Therefore the age differential seen between co-residing and non-coresiding women is not reflective of a trend of younger couples living alone and then moving in with their in-laws later in life. There was no statistical difference in the percentage of living fathers-in-law between the women who co-resided and those that did not, suggesting that father-in-law death is not associated with mother-in-law coresidence. If there is selective sorting into co-residence status, our data suggest that this occurs at the time of marriage. We also note that $93 \%$ of strictly co-residing women's father-in-laws were deceased, suggesting that perhaps widowed mothers are more likely to move into their son's apartment unit. Therefore we are fairly confident that in our sample of Upper Egyptian women, co-residence choice is not timed with a woman's post-marital work decisions.

Time-use data were only collected on one weekday in the life of each woman. Reported time use did not capture activities that were important but did not occur on each weekday. Better time-use data would be able to capture information about how women spend their time over multiple days, to even out any unusual patterns due to the day of the week or other factors. Additionally, we lack detailed data about husband's labor and time use, or the wages offered to each woman, both of which would have been valuable to include in the model. We are also limited by not having extensive information about variations in the labor market women faced, particularly the availability of public sector jobs compared to other types of job.

Data about mothers-in-law were only collected about the co-residing mothers-inlaw and therefore we do not have information about the disability status of the mothersin-law who do not co-reside. If mothers-in-law who are disabled but do not co-reside also impact the time use and work of their daughters-in-law, in the same way as coresiding mothers-in-law impact their daughters-in-law, then we are over-estimating the effect of co-residing mothers-in-law. Additionally, we have no data on fathers-in-law or the respondent's own parents' disability status, and subsequent caregiving needs. 


\section{Conclusions}

This study shows that co-residing with mothers-in-law who are disabled is associated with decreased likelihood of women working and fewer minutes per day spent working among women of childbearing age in Upper Egypt, compared to non-co-residing women and women co-residing with a healthy mother-in-law. This may be through selfselection or the imposition of more traditional roles by seniors, and it could be mediated by inter-generational exchanges of caregiving in the household.

With increasing life expectancy in Egypt, women are likely to spend more of their lives in co-resident situations. Additionally, with lower fertility, each family has fewer sons: therefore the probability that a woman will live with her in-laws will increase. If Egypt's health transition lengthens the expected years of disability for seniors, younger women in Egypt are likely to spend more time caring for aging in-laws, hindering their ability to join the labor force. Egypt today has few other, non-familial, options for oldage support. However, if there is a reduction in disability with increased life expectancy, co-residence could give women of reproductive age more free time to devote to other activities in the years to come.

\section{Acknowledgments}

The authors acknowledge the generous support of The Bill and Melinda Gates Institute for Population and Reproductive Health. 


\section{References}

Al-Qudsi, S. (1998). Labour participation of Arab women: estimated of the fertility to labour supply link. Applied Economics 30(7): 931-941. doi:10.1080/000368498 325363.

Antecol, H. (2003). Why is there Cross-Country Variation in Female Labor Force Participation Rates? The Role of Male Attitudes Toward Family and Sex Roles. Claremont Colleges Working Paper In Economics.

Assaad, R. (2004). Why Did Economic Liberalization Lead to Feminization of the Labor Force in Morocco and De-feminization in Egypt? Paper presented at the The Center of Arab Women Training and Research (CAWTAR) Mediterranean Development Forum (MDF).

Assaad, R. (2009). The Egyptian Labor Market Revisited. Cairo, Egypt: American University in Cairo Press. doi:10.5743/cairo/9789774162480.001.0001.

Assaad, R. and Zouari, S. (2003). The Timing of Marriage, Fertility, and Female Labor Force Participation in Morocco. Paper presented at the The Ninth Annual Conference of the Economic Research Forum, UAE. .

Becker, G.S. (1981). A Treatise on the Family (Second Edition). Cambridge: Harvard University Press.

Bianchi, S.M., Milkie, M.A., Sayer, L.C., and Robinson, J.P. (2000). Is Anyone Doing the Housework? Trends in the Gender Division of House- hold Labor. Social Forces 79: 191-228. doi:10.1093/sf/79.1.191.

Central Agency for Mobilization and Statistics. (2006). Egypt General Census for Population, Housing, and Establishments. Egypt.

Cunningham, S.A., Yount, K.M., Engelman, M., and Agree, E. (2013). Returns on Lifetime Investments in Children in Egypt. Demography 50: 699-724. doi:10.1007/s13524-012-0147-3.

El-Hamidi, F. (2003). Poverty and Labor Supply of Women: Evidence from Egypt. Paper presented at the Tenth Annual Conference of the Economic Research Forum (ERF).

Fries, J. (1980). Aging, Natural Death and the Compression of Morbidity. New England Journal of Medicine 303(3): 245-250. doi:10.1056/NEJM198007173030304.

Gronau, R. (1973). The Intrafamily Allocation of Time: the Value of the Housewives' Time. American Economic Review 63: 634-651. 
Hendy, R. (2011). Rethinking the Time Allocation of Egyptian Females: A Matching Analysis. Gender and World in the MENA Region Working Paper Series: Poverty, Job Quality and Labor Market Dynamics. Population Council 17.

Hindin, M.J. (2000). Women's autonomy, women's status and fertility-related behavior in Zimbabwe. Population Research and Policy Review 19: 255-282. doi:10.1023/A:1026590717779.

Inglehart, R. and Norris, P. (2003). The True Clash of Civilizations. Foreign Policy 135: 62-70. doi:10.2307/3183594.

Johnson, R. and Lo Sasso, A. (2006). The Impact of Elder Care on Women's Labor Supply. Inquiry 43(3): 195-210. doi:10.5034/inquiryjrnl_43.3.195.

Kimmel, J. and Connelly, R. (2007). Mothers' Time Choices: Caregiving, Leisure, Home Production, and Paid Work. The Journal of Human Resources 42(3): 643681.

Knodel, J.E., Friedman, J., Anh, T.S., and Cuong, B.T. (2000). Intergenerational Exchanges in Vietnam: Family Size, Sex Composition, and the Location of Children. Population Studies: A Journal of Demography 54(1): 89-104.

Lane, S. and Meleis, A. (1991). Roles, Work, health Perceptions, and Health Resources for Women: A study in an Egyptian Delta Hamlet. Social Science and Medicine 33(10): 1197-1208. doi:10.1016/0277-9536(91)90236-6.

Langsten, R. and Salem, R. (2008). Two Approaches to Measuring Women's Work in Developing Countries: A Comparison Survey of Data from Egypt. Population and Development Review 34(2): 283-305. doi:10.1111/j.1728-4457.2008.0022 0.x.

Latif, E. (2006). Labour Supply Effects of Informal Caregiving in Canada. Canadian Public Policy / Analyse de Politiques 32(4): 413-429.

Linos, N., Khawaja, M., and Al-Nsour, M. (2010). Women's Autonomy and Support for Wife Beating: Findings From a Population-Based Survey in Jordan. Violence and Victims 25(3). doi:10.1891/0886-6708.25.3.409.

Mason, K.O. (2005). Measuring Women's Empowerment: Learning from CrossNational Research. In Narayan, D. (ed.). MEASURING EMPOWERMENT: Cross-Disciplinary Perspectives. Washington DC: The World Bank.

Maurer-Fazio, M., Connelly, R., Chen, L., and Tang, L. (2011). Childcare, eldercare, and labor force participation of married women in urban China, 1982-2000. Journal of Human Resources 46: 261-294. doi:10.1353/jhr.2011.0011. 
Muntifering Cox, C., Hindin, M.J., Otupiri, E., and Larsen-Reindorf, R. (2013). Understanding Couples' Relationship Quality And Contraceptive Use in Kumasi, Ghana. International Perspectives on Sexual and Reproductive Health 39(4). doi:10.1363/3918513.

Namaro, S. and Roushdy, R. (2009). Intrahoushold Resource Allocation in Egypt: Women Emplowerment and investment in children. Middle East Development Journal 1(1).

Oeppen, J. and Vaupel, J.W. (2002). Broken Limits to Life Expectancy. Science 296: 1029-2031. doi:10.1126/science.1069675.

Roushdy, R. (2004). Intrahousehold Resource Allocation in Egypt: Does Women's Empowerment Lead to Greater Investments in Children? Working Paper 0410. Retrieved from http://www.erf.org.eg/CMS/uploads/pdf/0410_final.pdf.

Roushdy, R. and Namaro, S. (2007). Intrahousehold Resource Allocation in Egypt: Effect of Power Distribution within the Household on Child Work and Schooling. Working Paper 331. Retrieved from http://www.econ.pitt.edu/papers/ Soiliou_GerpaModified.pdf.

Sasaki, M. (2002). Causal Effect of Family Structure on Labor Force Participation among Japanese Married Women. Journal of Human Resources 37(2): 429-440. doi:10.2307/3069654.

Sayer, L.C. (2005). Gender, Time and Inequality: Trends in Women's and Men's Paid Work, Unpaid Work and Free Time. Social Forces 84(1): 285-303. doi:10.1353/ sof.2005.0126.

Shin, H. (2013). Coresident Extended Kin and Time Allocation Among Employed Mothers in Mexico. Journal of Family Issues 34(7): 918-951. doi:10.1177/0192 $513 X 12448740$.

Sinunu, M., Yount, K.M., and El Afify, N.A.W. (2008). Informal and Formal Longterm Care for Frail Older Adults in Cairo, Egypt: Family Caregiving Decisions in a Context of Social Change. J Cross Cult Gerontol 24: 63-76. doi:10.1007/ s10823-008-9074-6.

United Nations, D.o.E.a.S.A., Population Division, New York (2011). World Population Prospects: The 2010 Revision, (comprehensive Excel tables) Retrieved January 7 2013, from http://data.un.org/Data.aspx?d=PopDiv\&f= variableID\%3A44. 
United Nations Statistics Division (2014). World Statistics Pocketbook, Egypt. Series V, No. 38. Retrieved from http://unstats.un.org/unsd/pocketbook/PDF/ Egypt.pdf.

Upadhyay, U.D. and Karasek, D. (2012). Women's Empowerment and Ideal Family Size: An Examination of DHS Empowerment Measures In Sub-Saharan Africa. International Perspectives on Sexual and Reproductive Health 38(2). doi:10.1363/3807812.

Üstün, T., Kostanjsek, N., Chatterji, S., and Rehm, J.(eds.) (2010). Measuring Health and Disability, Manual for WHO Disability Assessment Schedule: WHODAS 2.0.

Vatuk, S. (1998). The Indian woman in later life: some social and cultural consideration. In: Das Gupta, M., Chen, L.C., and Krishnan, T.N. (eds.). Women's health in India: risk and vulnerability. New Delhi: Oxford India Paperbacks: 289-306.

Wakabayashi, C. and Donato, K. (2005). The Consequences of Caregiving: Effects on Women's Employment and Earnings. Population Research and Policy Review 24: 467-488. doi:10.1007/s11113-005-3805-y.

Wolf, D.A. and Soldo, B.J. (1994). Married Women's Allocation of Time to Employment and Care of Elderly Parents. The Journal of Human Resources 29(4): 1259-1276. doi:10.2307/146140.

World Bank (2010). Bridging the Gap: Improving Capabilities and Expanding Opportunities for Women in the Middle East and North Africa Region, from http://siteresources.worldbank.org/INTMENA/Resources/Gender-pub.pdf.

Yount, K.M. (2005). The Patriarchal Bargain and Intergenerational Coresidence in Egypt. The Sociological Quarterly 46(1): 137-164. doi:10.1111/j.15338525.2005.00007.x.

Yount, K.M., Cunningham, S.A., Engelman, M., and Agree, E. (2012). Gender and Material Transfers between Older Parents and Children in Ismailia, Egypt. Journal of Marriage and Family 74(1): 116-131. doi:10.1111/j.1741-3737.2011. 00881.x.

Yount, K.M. and Sibai, A.M. (2009). Demography of Aging in Arab Countries. In: Uhlenberg, P. (ed.). International Handbook of Population Aging. Springer Science+Business Media: 277-315. doi: 10.1007/978-1-4020-8356-3_13. 
Diamond-Smith, Bishai \& El Gibaly: Co-residence and women's time use in Egypt 